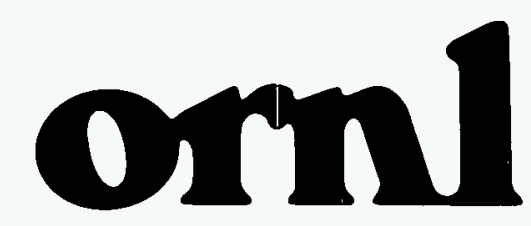

OAK RIDGE NATIONAL LABORATORY

MARTIN MARIETTA
RECFIVED

JUL 2 o 1995

OSTI

Investigation of the Liquid Low-Level Waste Evaporator Steam Coil Failure and Supporting Laboratory Studies

\author{
S. J. Pawel \\ J. R. Keiser \\ H. F. Longmire
}


This report has been reproduced directly from the best available copy.

Available to DOE and DOE contractors from the Office of Scientific and Technical Information, P.O. Box 62, Oak Ridge, TN 37831; prices available from (615) 576-8401, FTS 626-8401.

Available to the public from the National Technical Information Service, U.S. Department of Commerce, 5285 Port Royal Rd., Springfield, VA 22161.

This report was prepared as an account of work sponsored by an agency of the United States Government. Neither the United States Government nor any agency thereof, nor any of their employees, makes any warranty, express or implied, or assumes any legal liability or responsibility for the accuracy, completeness, or usefuiness of any information, apparatus, product, or process disclosed, or represents that its use would not infringe privately owned rights. Reference herein to any specific commercial product, process, or service by trade name, trademark, manufacturer, or otherwise, does not necessarily constitute or imply its endorsement, recommendation, or favoring by the United States Government or any agency thereof. The views and opinions of authors expressed herein do not necessarily state or reflect those of the United States Government or any agency thereof. 


\section{DISCLAIMER}

Portions of this document may be illegible in electronic image products. Images are produced from the best available original document. 
Metals and Ceramics Division

\section{INVESTIGATION OF THE LIQUID LOW-LEVEL WASTE EVAPORATOR STEAM COIL FAILURE AND SUPPORTING LABORATORY STUDIES}

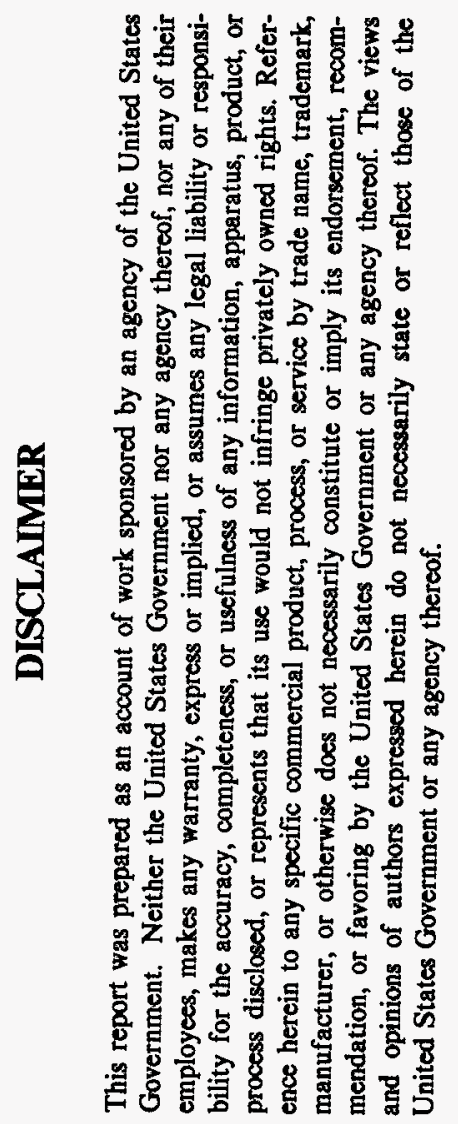

S. J. Pawel, J. R. Keiser, and H. F. Longmire

Date Published: May 1995

Prepared for

U.S. Department of Energy

Office of Environmental Management

EW 3120041

Prepared by the

OAK RIDGE NATIONAL LABORATORY

Oak Ridge, Tennessee 37831-6285

managed by

Lockheed Martin Energy Systems

for the

U.S. DEPARTMENT OF ENERGY

under contract DE-AC05-84OR21400 
. 
TABLE OF CONTENTS

$\underline{\text { Page }}$

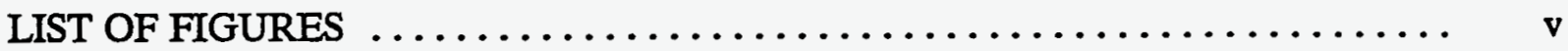

LIST OF TABLES $\ldots \ldots \ldots \ldots \ldots \ldots \ldots \ldots \ldots \ldots \ldots \ldots \ldots \ldots \ldots \ldots \ldots \ldots \ldots \ldots \ldots$ vii

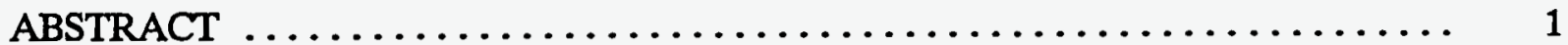

1. INTRODUCTION AND OPERATING HISTORY ................ 1

2. RESULTS AND DISCUSSION OF STEAM COIL

FAILURE INVESTIGATION $\ldots \ldots \ldots \ldots \ldots \ldots \ldots \ldots \ldots \ldots \ldots \ldots \ldots \ldots \ldots$

3. RESULTS AND DISCUSSION OF EVAPORATOR COIL MEASUREMENTS FROM NEW VESSEL $\ldots \ldots \ldots \ldots \ldots \ldots \ldots \ldots \ldots, 17$

4. RESULTS AND DISCUSSION FROM SUPPORTING LABORATORY TESTS .......................... 20

5. EVAPORATOR EXPERIENCE AT OTHER DEPARTMENT OF ENERGY SITES $\ldots \ldots \ldots \ldots \ldots \ldots \ldots \ldots \ldots \ldots, 27$

6. PERTINENT LITERATURE INFORMATION ON

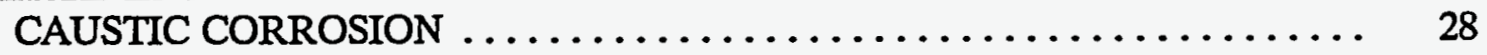

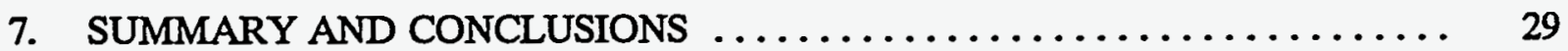

8. RECOMMENDATIONS ............................. 31

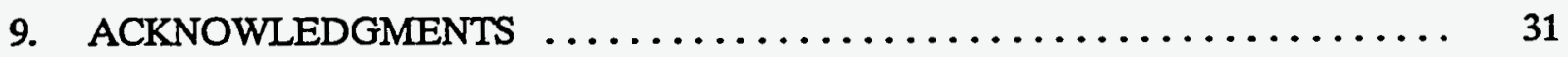

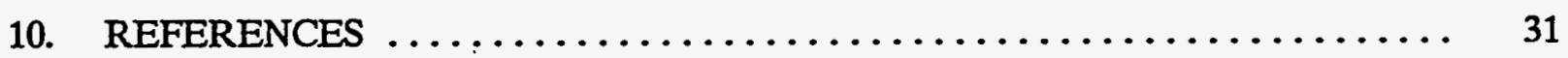

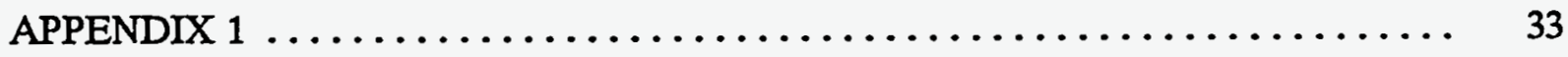


• 


\section{LIST OF FIGURES}

Figure

Page

1 Example of a section of steam coil showing a region where the surface deposit appears relatively thin or removed. To help with relative magnification, recall that the pipe diameter is 1.9 in.

2 Leak positions in failed steam coil. Mounting bracket is at right and leak positions facing camera are marked with arrows.

A third leak site was on the side of the pipe away from the camera just left of the bracket. To help with relative magnification, recall that the pipe diameter is $1.9 \mathrm{in}$.

3 Sketch of pipe section removed from evaporator and relative position of metallography specimens $\ldots \ldots \ldots \ldots \ldots \ldots \ldots \ldots \ldots \ldots$

$4 \quad$ Collage micrograph from as-polished cross section near leak site.

For comparison, the thin spot of wall thickness is about

0.010 in. thick

5 As-polished cross section near thin region of Fig. 4

on process side

6 As-polished cross section at a leak site at (a) $100 x$

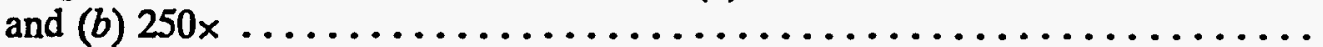

$7 \quad$ As-polished cross section from region suspected of bearing cracks based on macroscopic observation at (a) $100 \times$ and $(b) 500 \times \ldots \ldots \ldots \ldots \ldots$

8 As-polished cross sections of steam coil specimens showing "nonuniform" nature of attack on process side of pipe

9 Etched cross section of steam coil specimen 



\section{LIST OF TABLES}

Table

1 Cooling coil pipe wall thickness (inches) as a function of position

2 Wall thickness measurements for representative steam coils at a bend position

3 Composition (weight percent) of coupon materials used in this investigation

$4 \quad$ Description of test solutions (made with reagent grade chemicals and demineralized water)

5 Corrosion rates based on weight loss of coupons exposed $24 \mathrm{~h}$ to $41 \% \mathrm{NaOH}$

6 Corrosion rates (mils per year) calculated from weight loss for coupons exposed in acidified surrogate sludge (nitric acid addition to $\mathrm{pH}$ near 0 ) with approximately $500 \mathrm{ppm}$ fluoride addition

7 Corrosion rates based on weight loss for the "bake to dryness"

experiments 

Editor's Note: Although Oak Ridge National Laboratory has a policy of reporting its work in SI metric units, this report uses English units in some instances, primarily in the reporting of dimensions. The justification is that the significant measurements were collected in these units, and the operating facility (design drawings, field measurements) can make best use of these units. Reporting dimensions in other units would compromise the utility of the report to the intended readership. To assist the reader in obtaining the SI equivalents, these are listed below for the units occurring in this report:

Property

Dimension

Dimension

Dimension

Pressure $\underline{\text { Unit used }}$

in.

mil (0.001 in.)

$\mathrm{ft}$

psi
SI equivalent

$25.4 \mathrm{~mm}$

$25.4 \mu \mathrm{m}$

$0.3048 \mathrm{~m}$

6.896 MPa 


\title{
INVESTIGATION OF THE LIQUID LOW-LEVEL WASTE EVAPORATOR STEAM COIL FAIIUURE AND SUPPORTING LABORATORY STUDIES*
}

\author{
S. J. Pawel, J. R. Keiser, and H. F. Longmire
}

\begin{abstract}
Using a remote video camera, the internals of a low-level waste evaporator tank (termed 2A2, type 304L stainless steel construction, known to have failed steam coils) were inspected. This inspection revealed at least three rather substantial holes as opposed to crack- or pit-like leak sites near the nominal solution level position on one particular steam coil. This section was removed from the evaporator vessel, and subsequent hot cell examination revealed extensive general corrosion on the process side of the coil with little or no attack on the steam side. Hot cell metallography confirmed intense general corrosion on the process side and, in addition, revealed shallow intergranular attack at the leading edge of corrosion. No pits or cracks were detected in this section of the steam coil. Laboratory corrosion tests with coupons of 304L (and other high-alloy materials) isothermally exposed in a range of solutions similar to those expected in the evaporator reveal only very low corrosion rates below $40 \%$ sodium hydroxide and the solution boiling point. However, "dried film" experiments revealed that much more dilute solutions became aggressive to stainless steel due to concentrating effects (evaporation and periodic wetting) at the air/solution interface. The high general corrosion rates observed on the failed coil section occurred at or near the air/solution interface and were attributed to such "splash zone" activity.
\end{abstract}

\section{INTRODUCTION AND OPERATING HISTORY}

The liquid low-level waste (LLW) evaporator system collects dilute radioactive wastes from a variety of facilities across the Oak Ridge National Laboratory (ORNL). As originally generated, the various wastes are typically acidic, but these are neutralized with an excess of caustic prior to evaporation. In batch processing, these alkaline wastes are heated (with steam coils inside a tank), and water is evaporated to reduce the volume of the wastes. Subsequently, the waste concentrate is stored in the Melton Valley Storage Tank system. The waste concentrate typically includes a high fraction of insoluble solids, mostly hydroxides and carbonates, in a thick nitrate-slurry of $\mathrm{pH}$ near 13.

*Research sponsored by the U.S. Department of Office of Environmental Waste, U. S. Department of Energy under contract DE-AC05-84OR21400 with Lockheed Martin Energy Systems. 
The evaporators are vertical, type 304L stainless steel (hereafter called 304L) tanks on the order of $10 \mathrm{ft}$ in diameter and somewhat taller. Seven helical steam coils (also 304L stainless steel) enter the vessel near the top of the tank, wind in concentric circles near the bottom, and then exit the vessel at the top. The coils carry steam at about 35 psi (about $125^{\circ} \mathrm{C}$ ) for heating the solution.

The performance of the evaporators has been largely successful, but there have been a few incidences of steam coil failures. The original evaporator, ${ }^{1}$ termed A2, was designed in 1962 to meet requirements of Section VIII of the American Society of Mechanical Engineers (ASME) Pressure Vessel Code, was fabricated at ORNL, and was commissioned in 1965. This evaporator operated on and off into the mid-1980s without steam coil failures. A second evaporator, termed 2A2, and a "spare" were built in the mid-to-late 1970 s from essentially the same drawings as the original unit but were fabricated by an outside vendor to meet the somewhat more stringent requirements of Section III (nuclear vessel) of the ASME Pressure Vessel Code. The second evaporator (2A2) was commissioned ca. 1980. Within 2 years, one of the steam coils in the new evaporator failed, and shortly after, two more coils failed. Except for a few brief shutdown periods, the $2 \mathrm{~A} 2$ evaporator was operated for some time on a batch basis with the failed steam coils plugged.

The original failure analysis ${ }^{1}$ of the $2 \mathrm{~A} 2$ steam coils was necessarily limited. No physical observation of the failed surfaces, or even determination of the specific failure site, was possible due to the need for continued operation and the presence of a radioactive environment. However, four plausible causes of failure could be postulated:

1. a basic defect or flaw in the coil design/specification,

2. inherent material defect or one incurred during fabrication,

3. damage to the coils during shipment from the vendor site, and

4. off-design operation of the unit for an unspecified time.

A basic defect or flaw in the design was believed to have a very low probability due to the successful operation of the steam coils in the original A2 unit. The A2 unit was built from the same drawings and, at least on paper, to a less stringent ASME code than the $2 \mathrm{~A} 2$ unit. Further, coil-in-a-tank technology is standard, and the rather thick wall pipe specified for the coil was 
considered very conservative. An inherent material defect was also considered as having very low probability, primarily because the paper trail of quality assurance steps was deemed to have been both significant and appropriate to eliminate any reasonable problems.

Damage to the coils during shipment from the vendor was assigned a slightly higher probability of occurrence. The two newer units (the $2 \mathrm{~A} 2$ and the spare) were shipped in a horizontal configuration even though they had been designed to be operated in a vertical orientation. The thought was that, due to lack of proper support, the coil bundles may have been subject to vibrational (fatigue) loads during transit that substantially weakened (cracked) the flexure points near the coil inlet/outlet positions at the top of the tank. Since the location of the coil failures was unknown at the time of the original investigation, ${ }^{1}$ this possible cause was not definitively ruled out.

Operation of the evaporator under off-normal conditions was assigned some credibility. In at least one documented case, it was discovered that the evaporator feedstock was very acidic $(\mathrm{pH}$ near 1) rather than the nominal alkaline solution. Although the dates given in the original failure report $^{2}$ do not seem consistent, it was suggested that at least one such process upset occurred when the $2 \mathrm{~A}$ unit (which never experienced coil failure) was out of service. The implications of the temporary acidic condition are not particularly straightforward, but one concern was that of chloride stress-corrosion cracking (SCC) of the steam coils in this environment. Since the evaporator operated with coils partially exposed (instead of fully submerged in liquid) to act as foam breakers, chloride salts could concentrate to dangerous levels on the hot portions of the coils just above the solution line. During acidic operation, this could lead to chloride-induced SCC of the coils. It was pointed out that simple caustic SCC could occur by essentially the same mechanism. (Although not discussed in ref. 1, it is likely that the high nitrate concentration in the evaporator environment effectively inhibited caustic cracking.)

However, the manner in which the failures were detected is not indicative of SCC failures. Typically, SCC is a slow degradation that involves very tiny fissures and leaks that slowly accumulate to something more substantial. Apparently, the coil leaks were detected as a large and "catastrophic" increase of in-leakage to the steam side. This does not preclude small leaks being undetected for some time before the final failure, but it lessens the probability. 
Based on the suspected failure possibilities, the recommendations of the original report ${ }^{1}$ were:

1. determine failure site(s) on the steam coils, and attempt to differentiate between possible fatigue failure (leak near top of vessel) or SCC failure (leak at/near liquid level on coils);

2. minimize operation of the evaporators with coils exposed; and

3. carefully control $\mathrm{pH}$ to ensure alkaline condition in the evaporator during campaigns.

In October 1993, new information regarding the $2 \mathrm{~A} 2$ coil failure was obtained. A remote inspection video identified at least three failure sites on the steam coil bundle and indicated rather substantial holes as opposed to crack- or pit-type leak sites. Operations personnel determined that removal of a section of the leaking steam coil for analysis was in order, and the failure investigation was reopened. This report documents the activities and information generated as a result of this effort.

\section{RESULTS AND DISCUSSION OF STEAM COIL FAILURE INVESTIGATION}

A high-resolution video camera was adapted to permit remote inspection of the internal surfaces of an evaporator known to contain at least one failed steam coil. (W. D. Box of the ORNL Chemical Technology Division, who developed the camera, was responsible for collecting the film footage.) To improve the chances of detecting the coil failure site(s), the tank internals were washed/rinsed with a nitric acid solution (apparently three rinses, but other details of this procedure were not available to the authors) to remove most of the sludge deposits from the coils. After cleaning, the camera was lowered into the tank, and sections of the tank wall and steam coils were observed at close range and in some detail.

The videotape revealed substantial surface roughening on many portions of the tank internals, particularly the bottom half of the unit. From the videotape, it is not entirely obvious which rough spots represented an irregular deposit of crud/salt that was incompletely removed (or partially attacked) by the nitric acid rinse process and which (if any) represented penetration into metal. Using the shadows cast by the camera light, relative elevation could often be determined for various regions, but an absolute depth was impossible to determine. Although uncertain (only one small piece of steam coil was actually examined), the authors offer the opinion that most of the surface roughness is in a deposit layer on the pipe surface. 
Many "deposit" areas revealed a red/orange discoloration similar to common iron corrosion products. Among these areas on the coils were irregular oval regions displaying low elevation. These regions have an appearance similar to that of a spalled oxide from a heavily oxidized specimen. An example appears in Fig. 1 (photo prepared from the videotape). In at least a few instances, a dark spot, only a fraction of the area of the oval, appeared to be at an even lower elevation, which may represent partial penetration into the metal pipe.

Following the preliminary inspection, water was admitted to the suspect coil(s) while the camera panned for leak sites. One particular coil was observed to have at least two sizeable leaks (with at least one other leak in the same region but on the side of the pipe inaccessible to the camera). The obvious leak sites were separated by only a few inches on the topmost winding of the particular coil between a vertical bracket that holds a stack of pipe windings ("lower" end of the pipe) and the region just as the pipe turns to a vertical orientation ("upper" end of the pipe). Figure 2, prepared from the videotape, reveals the relative size and position of the leak sites detected in this manner. Although somewhat uncertain, Operations personnel indicate that this location roughly corresponds to the nominal height of solution during operation.

A section including the obvious leak sites was flame cut from the affected coil and transferred to the hot cell facility at Building 3525 for examination. The macroscopic examination revealed several significant findings. Perhaps most important, the leak sites did not appear to be the result of pitting or cracking but rather extreme general corrosion of the pipe wall over sizeable areas (more than a square inch). Pipe wall thickness measurements were accomplished with a micrometer handled with the remote manipulators at the hot cell. These measurements showed an essentially constant inside diameter (ID) for the pipe indicating little general internal corrosion and only small crud deposits on the steam side. However, at the "lower" end of the pipe (near the bracket position and nearest the holes in the pipe), the outside diameter (OD) had decreased by about 0.170 in. on average. With constant ID, this indicates that the wall thickness of the pipe (nominally $0.145 \mathrm{in}$.) had decreased to about 0.060 in. due to process side corrosion. In the immediate vicinity of the obvious hole sites (within a half inch or so of the hole edge), the average wall was much thinner and got progressively thinner as the hole site was approached.

Further, the normal observations associated with a typical pit (high corrosion rate in a very localized area) or a crack (brittle behavior when handling pipe or a visible discontinuity) were not noted during the macroscopic evaluation. On the inside of one section of pipe, some "crack-like" indications did appear in a region apparently remote from the actual failure sites. Although 


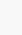




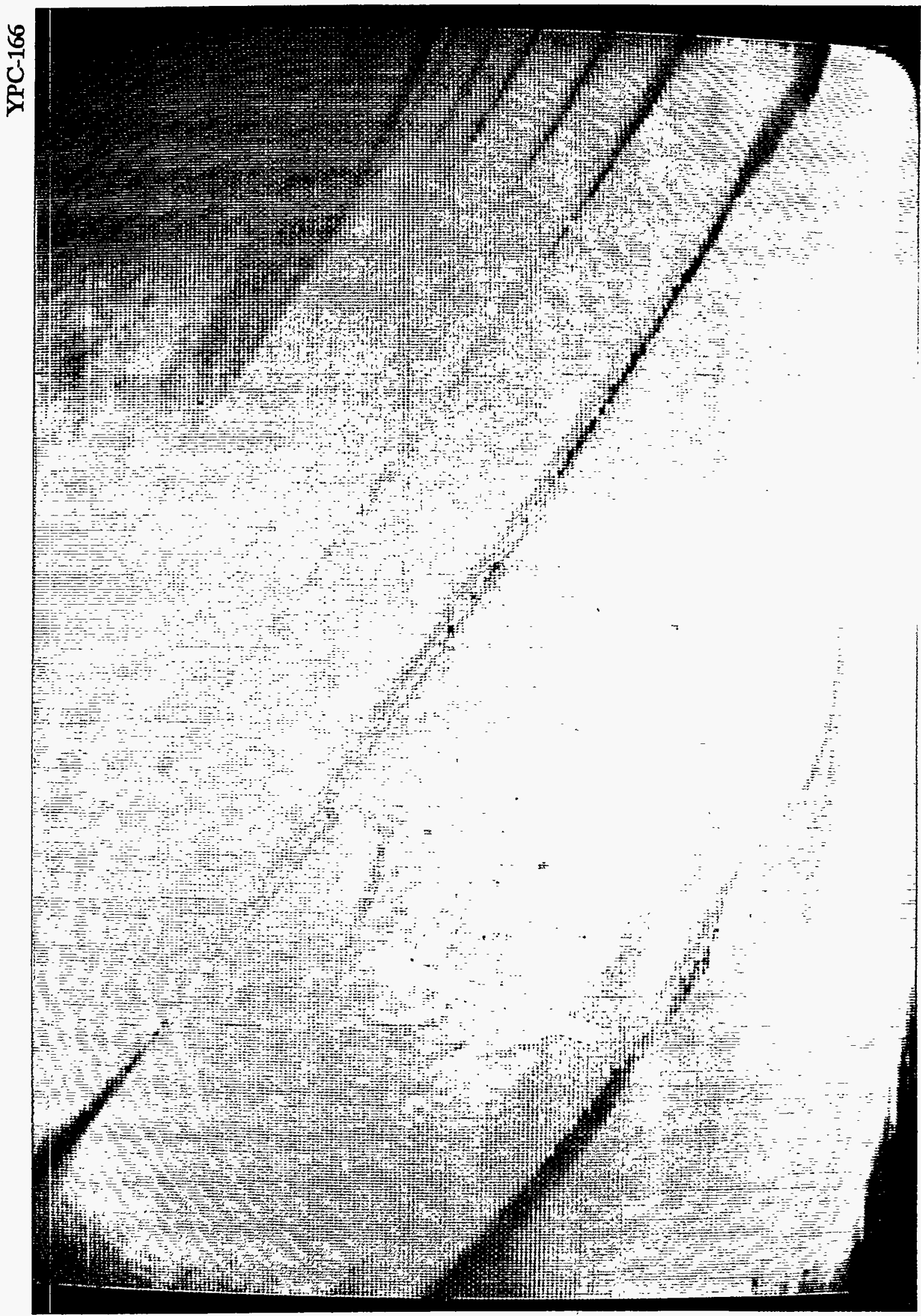




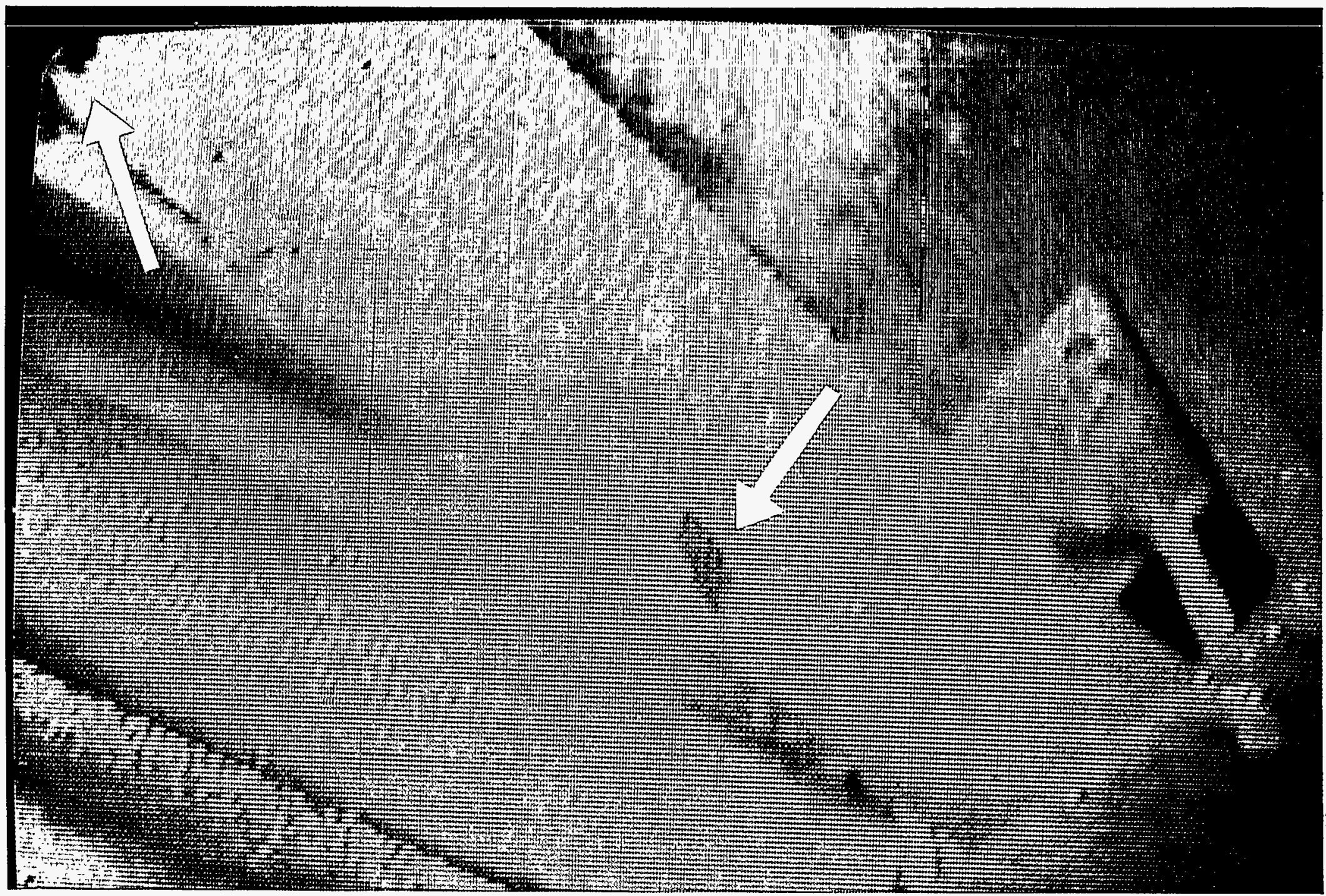

Fig. 2. Leak positions in failed steam coil. Mounting bracket is at right and leak positions facing camera are marked with arrows. A third leak site was on the side of the pipe away from the camera just left of the bracket. To help with relative magnification, recall that the pipe diameter is 1.9 in. 
significant scale is not expected on stainless steel in steam at $125^{\circ} \mathrm{C}$, it remains a fact that some apparent scale or debris was observed on the inside surface of the pipe, and the "crack-like" indications here may represent grooving in the scale or deposit.

Subsequently, samples of the pipe specimen were removed for hot cell metallography. These sections were selected as representative of the areas of major macroscopic observations on the pipe, and a sketch of the sample locations appears in Fig. 3. Primarily, metallography specimens were taken from sections 2 and 4 as marked. All pieces were labelled for future reference as required.

Figure 4 is a collage macrograph taken from a cross section of section 2 (defined in Fig. 3, about 0.25 in. from the edge of the leak site). The thin area nearest the hole is evident at the left of the collage. Note that the majority of wall thinning appears to have proceeded from the process (OD) side rather than the steam (ID) side of the coil, although there is some indication of similar corrosion attack on both the inside and outside of the pipe at this location. Presumably, some of the internal corrosion developed after the leak formed and steam to the coil was shut off, which allowed subsequent access of solution to the inside surface.

The most striking feature of the metallography of specimens from in and around an obvious failure site is the intergranular nature of attack at the advancing corrosion front. Figure 5 reveals the as-polished structure of the thin region shown in Fig. 4. The intergranular attack seems to precede the high general corrosion rate by only a grain diameter or so, but there is no doubt that it is intergranular at these locations. Grain dropping may be a feature leading to the high rate of general wall thinning. In a similar pattern, Fig. 6 shows the as-polished microstructure at the actual penetration point of the pipe (section 1 in Fig. 3).

The macroscopic examination revealed some areas exhibiting fine cracks or an otherwise crazed appearance (a region of section 4 in Fig. 3). Microstructural evaluation of the areas in question revealed no specific cracks but a pattern of intergranular corrosion somewhat more deep or intense than noted on other areas. Figure 7 is representative of this observation.

No classical pitting (e.g., subsurface cavity in metal larger than opening to environment, especially active area on an otherwise unattacked surface) was observed on the pipe sections prepared for metallographic evaluation. However, a limited number of "pit-like" areas were observed. Since the bottom and walls of these "pits" have the same intergranular attack morphology as the bulk surfaces exposed to hot waste in this region, it is suspected that these areas simply represent regions of unusually high corrosion rate and grain dropping due to a local 

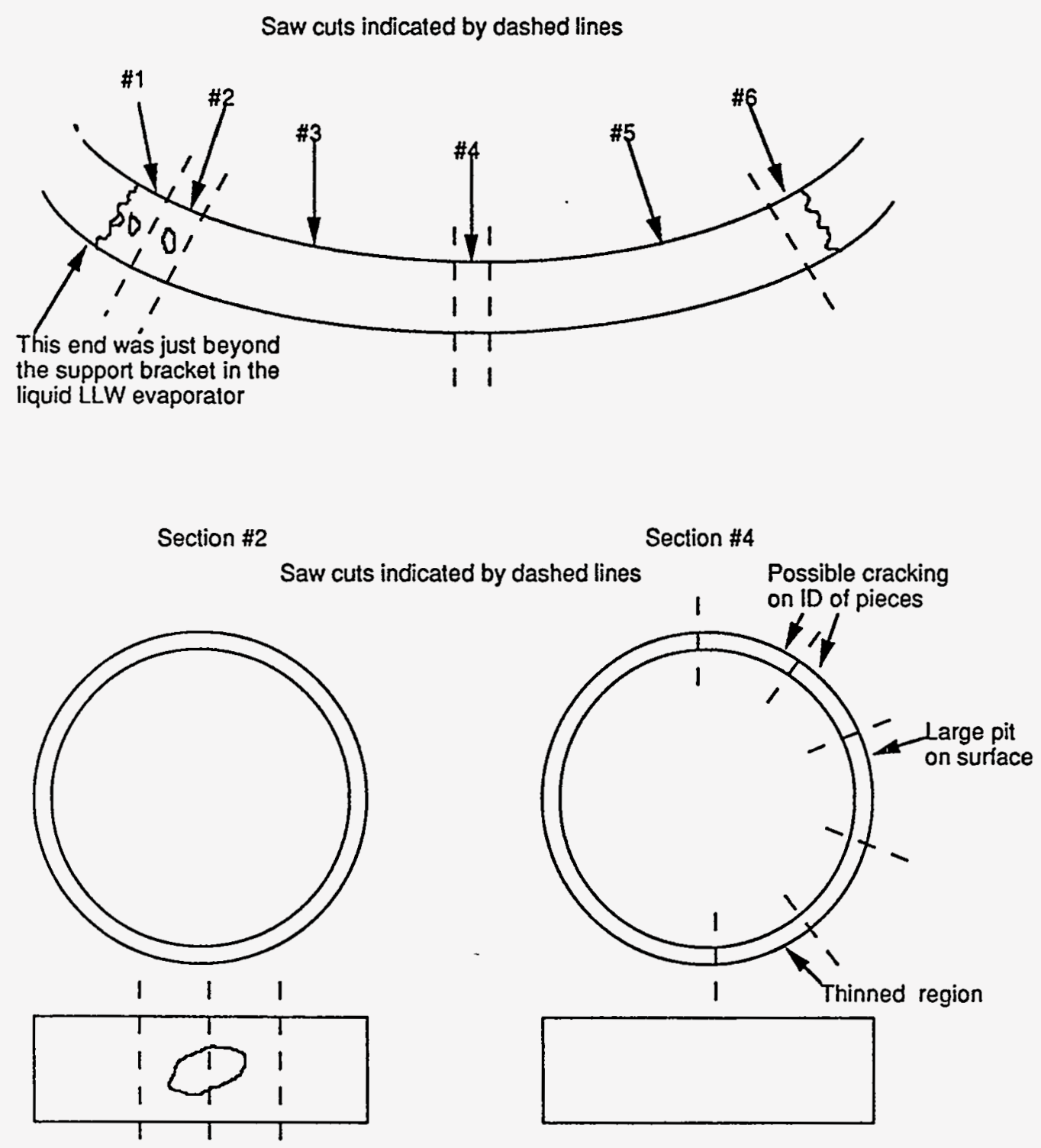

Fig. 3. Sketch of pipe section removed from evaporator and relative position of metallography specimens. 


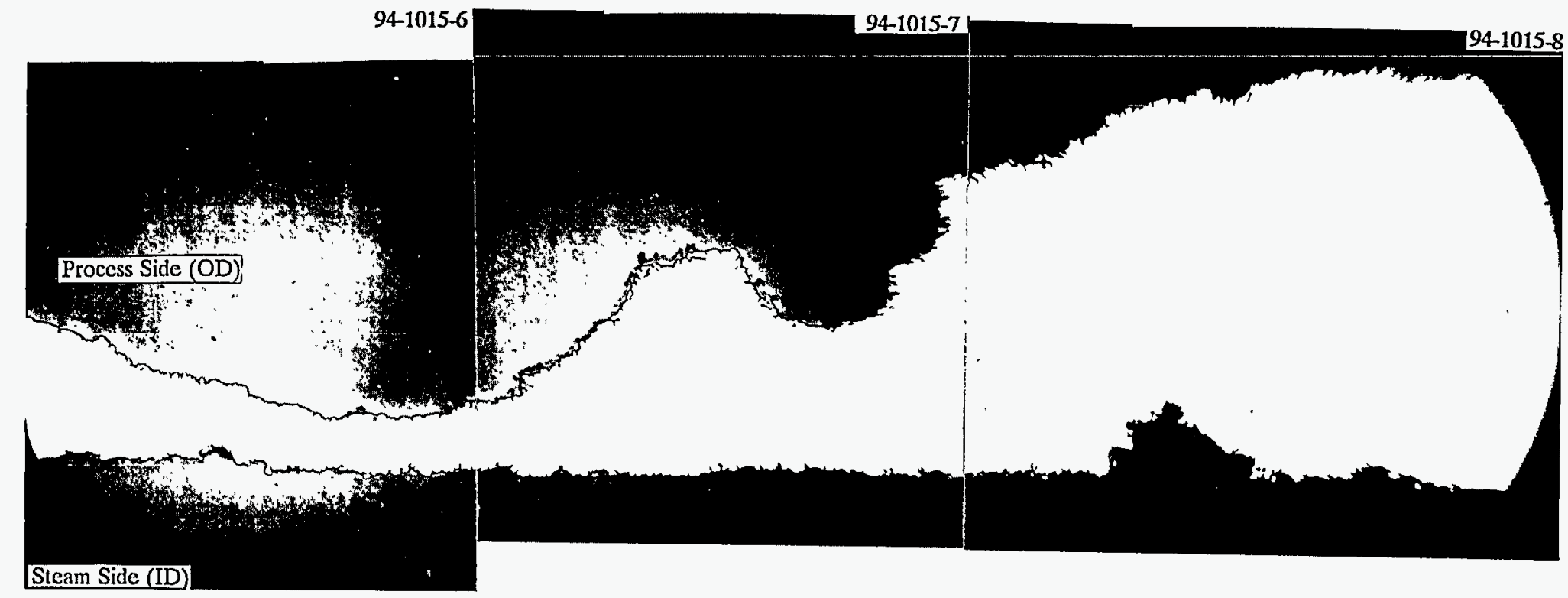

Fig. 4. Collage micrograph from as-polished cross section near leak site. For comparison, the thin spot of wall thickness is about 0.010 in. thick. 
94-1016-1

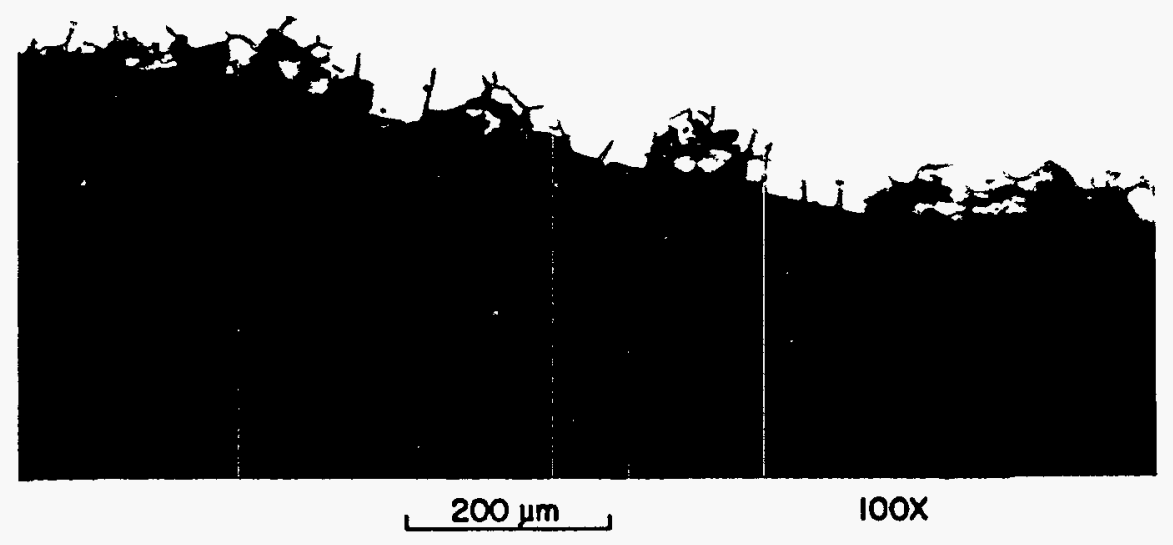

Fig. 5. As-polished cross section near thin region of Fig. 4 on process side. 
94-1014-1

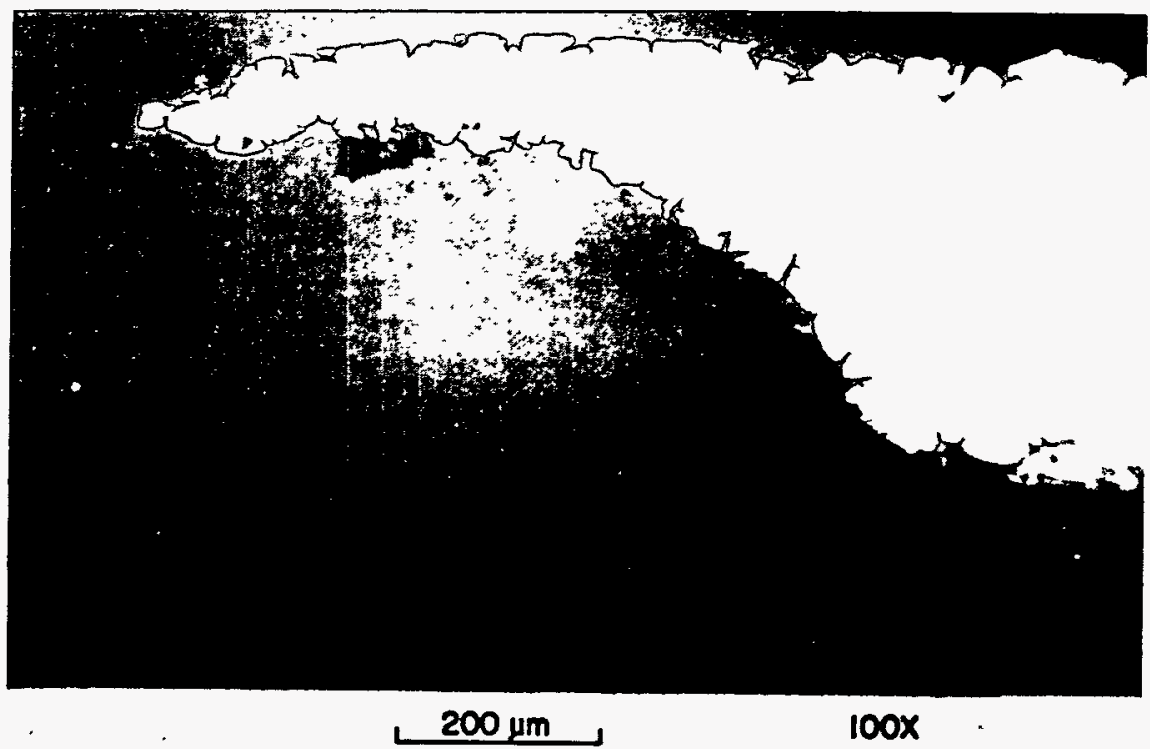

(a)

94-1014-2

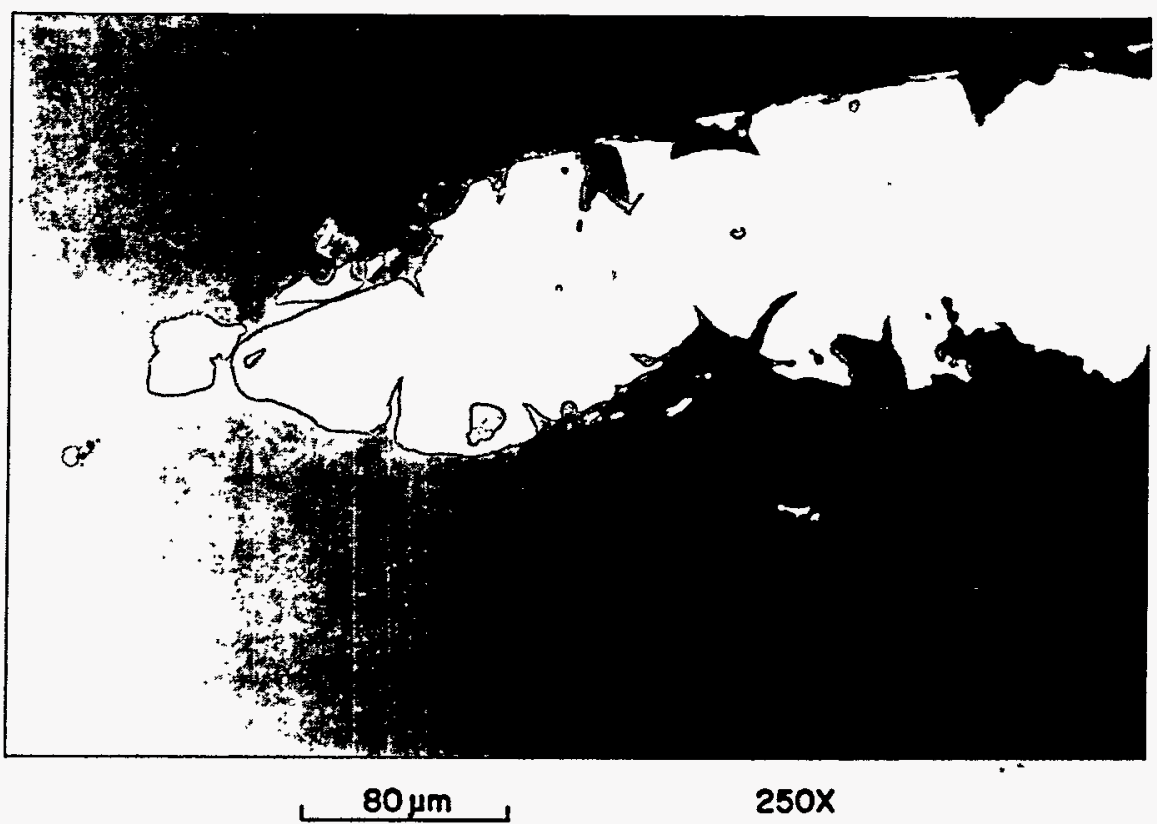

(b)

Fig. 6. As-polished cross section at a leak site at (a) $100 x$ and (b) $250 \times$. 


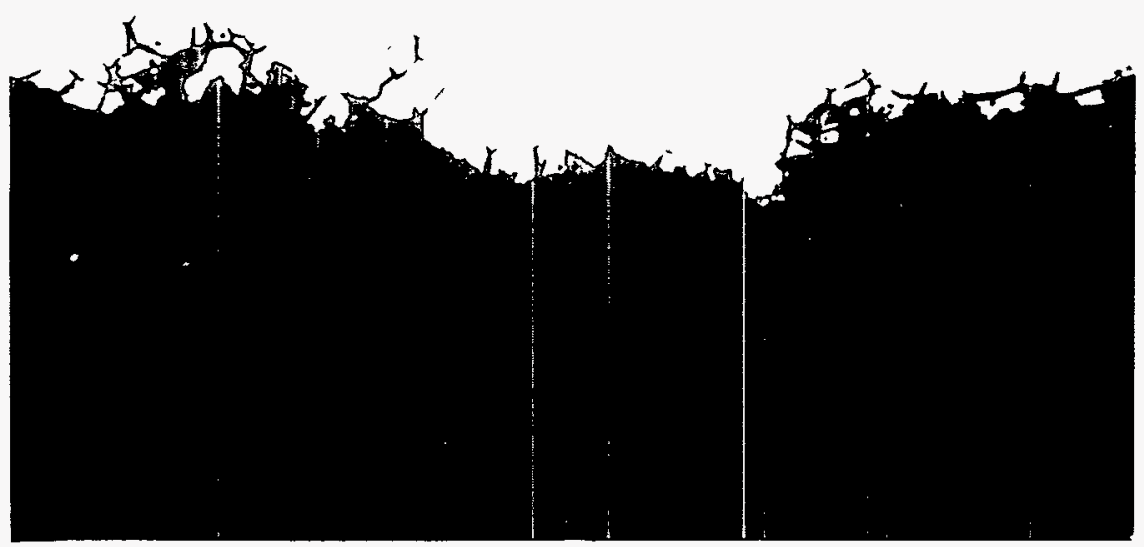

(a)

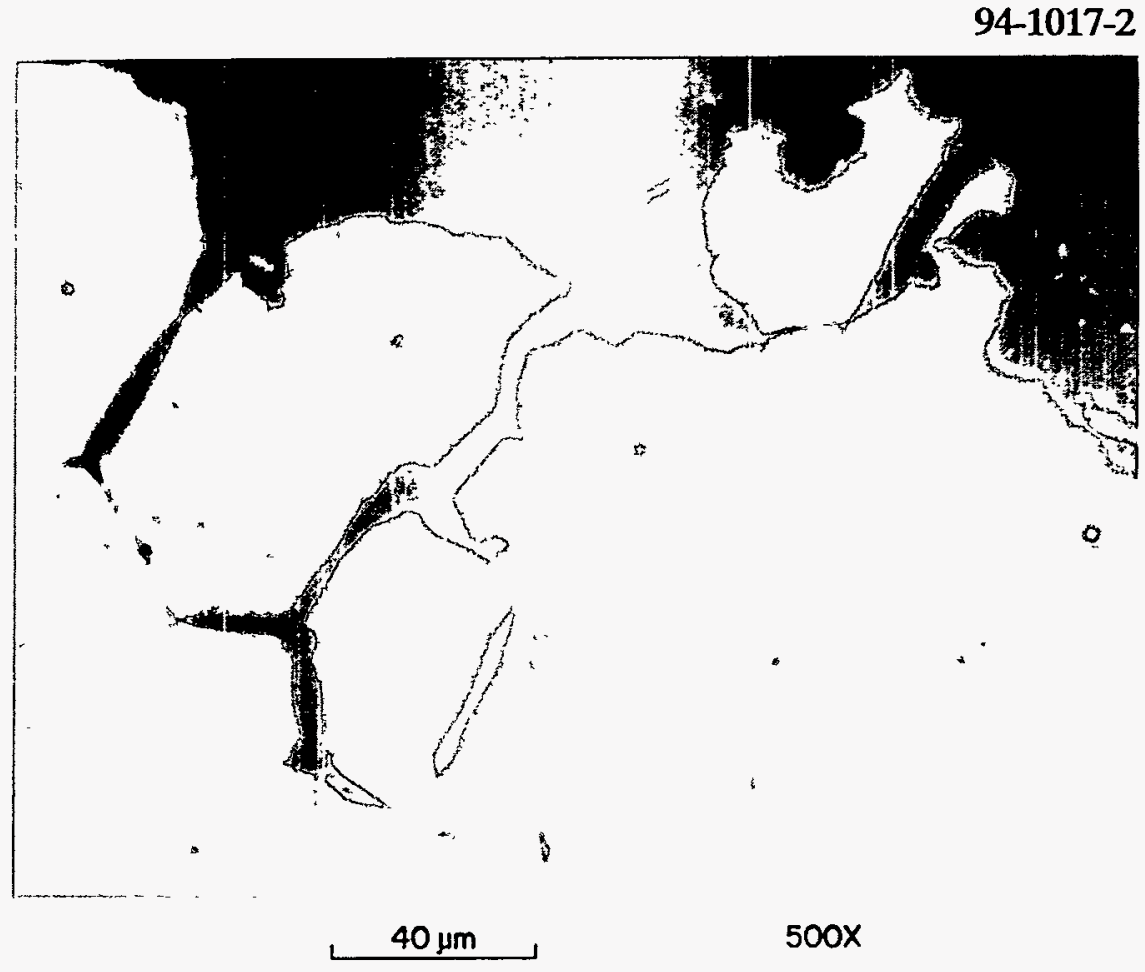

(b)

Fig. 7. As-polished cross section from region suspected of bearing cracks based on macroscopic observation at $(a) 100 \times$ and $(b) 500 \times$. 
salt deposit or some other factor that further accelerates the already high corrosion rate. Figure 8 shows representative examples of this "nonuniform" attack. Further, a region near the center of the collage in Fig. 4 shows a rather large "pit" of this type.

Following the examination of the specimens in the as-polished condition, the specimens were etched (swab in $10 \mathrm{~mL}$ nitric acid $+50 \mathrm{~mL}$ hydrochloric acid for 15 to $20 \mathrm{~s}$ ) to reveal the microstructure. The general absence of carbide precipitates (only steps at grain boundaries) suggests that neither poor heat treatment nor inappropriate carbon content of the (presumed) $304 \mathrm{~L}$ pipe material contributed to the high corrosion rate and failure. Figure 9 is representative of the etched microstructure.

\section{RESULTS AND DISCUSSION OF EVAPORATOR COIL MEASUREMENTS FROM NEW VESSEL}

Measurements of cooling coil wall thickness at selected locations were collected from a virgin evaporator vessel during construction activities in December 1993. Primarily, the purpose of these measurements was to assess the extent of wall thinning (comparison with the failed coil) that developed in the pipe as it was bent to the required coil shape/radius. Further, general wall thickness data of this type might be useful in a future investigation inside this evaporator, particularly if corrosion of the cooling coil continues to be significant.

The proximity of nearby radioactive feed/drain lines necessitated entry into the tank with respirators with supplied air lines and somewhat awkward protective clothing. This is significant in that it severely restricted mobility inside the tank and also limited time allowed inside the vessel. As a result, only a limited amount of data representing virgin coil thickness measurements was collected.

Inside the vessel, a "reproducible" position for coil wall thickness measurements was determined as follows. A group of four pipes rises from near the bottom center of the vessel, and the pipes run vertically to a height just sufficient to clear the highest horizontal winding of the group of coils. These four pipes then bend toward horizontal and go over the top of the coil windings toward the vessel wall. These four pipes are roughly equispaced, and standing at the bottom center of the tank facing these pipes, two pipes appear to bend slightly to the right and two to the left as they pass over the top of the coil group. Midway between the two centermost of these four pipes, a "12 o'clock" position was defined on the top of each pipe. (The line defining these 12 o'clock positions is, in effect, a radius of the tank.) Other measurement positions (on 


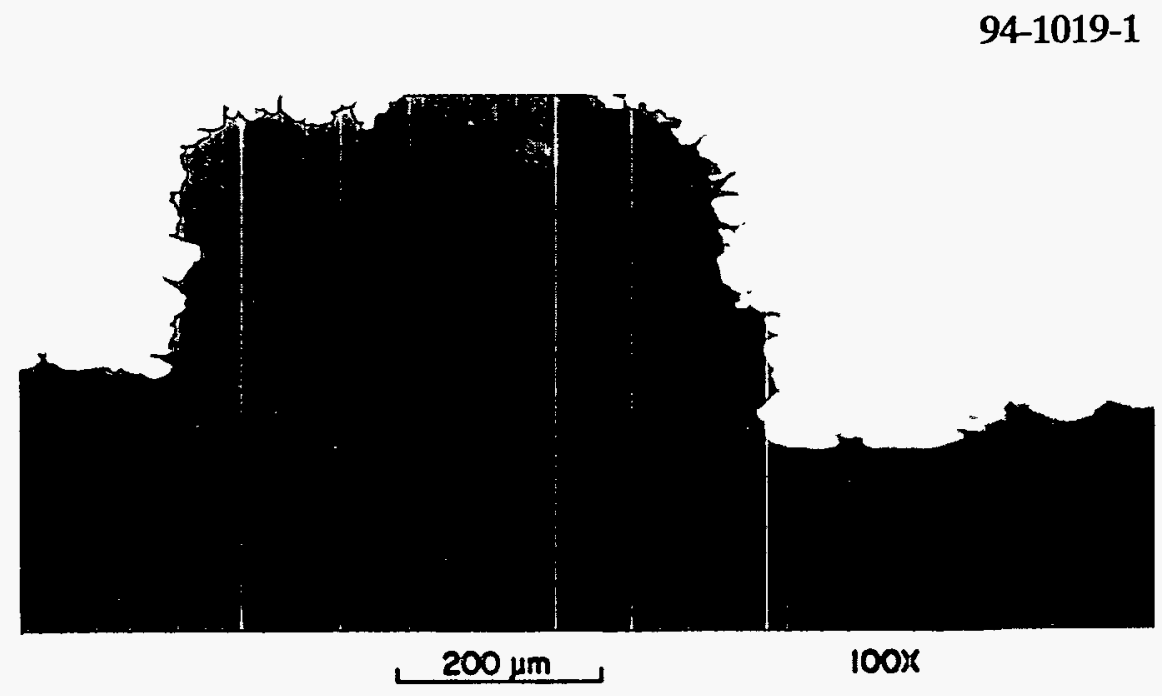

94-1018-1

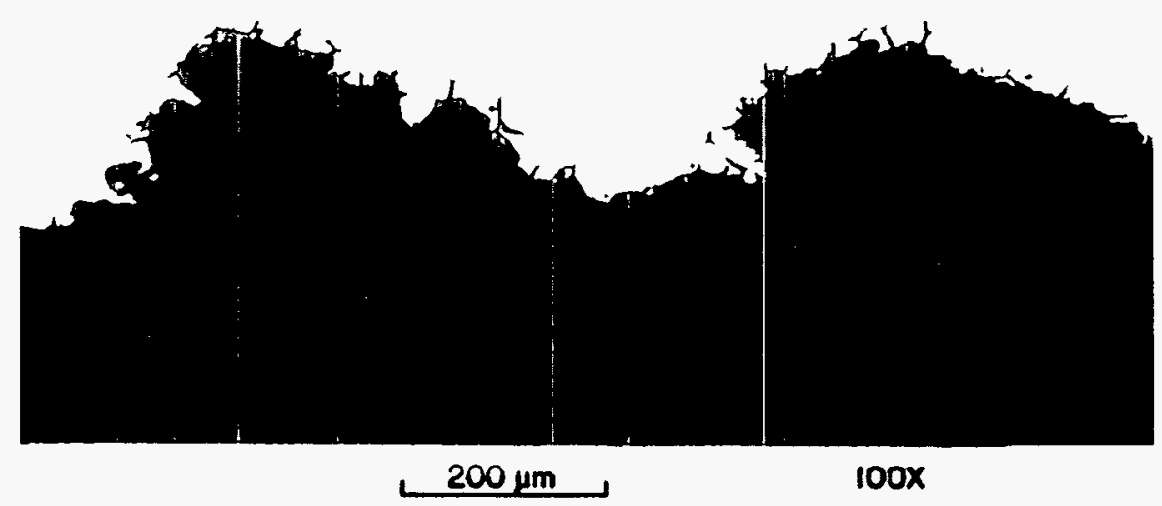

Fig. 8. As-polished cross sections of steam coil specimens showing "nonuniform" nature of attack on process side of pipe. 


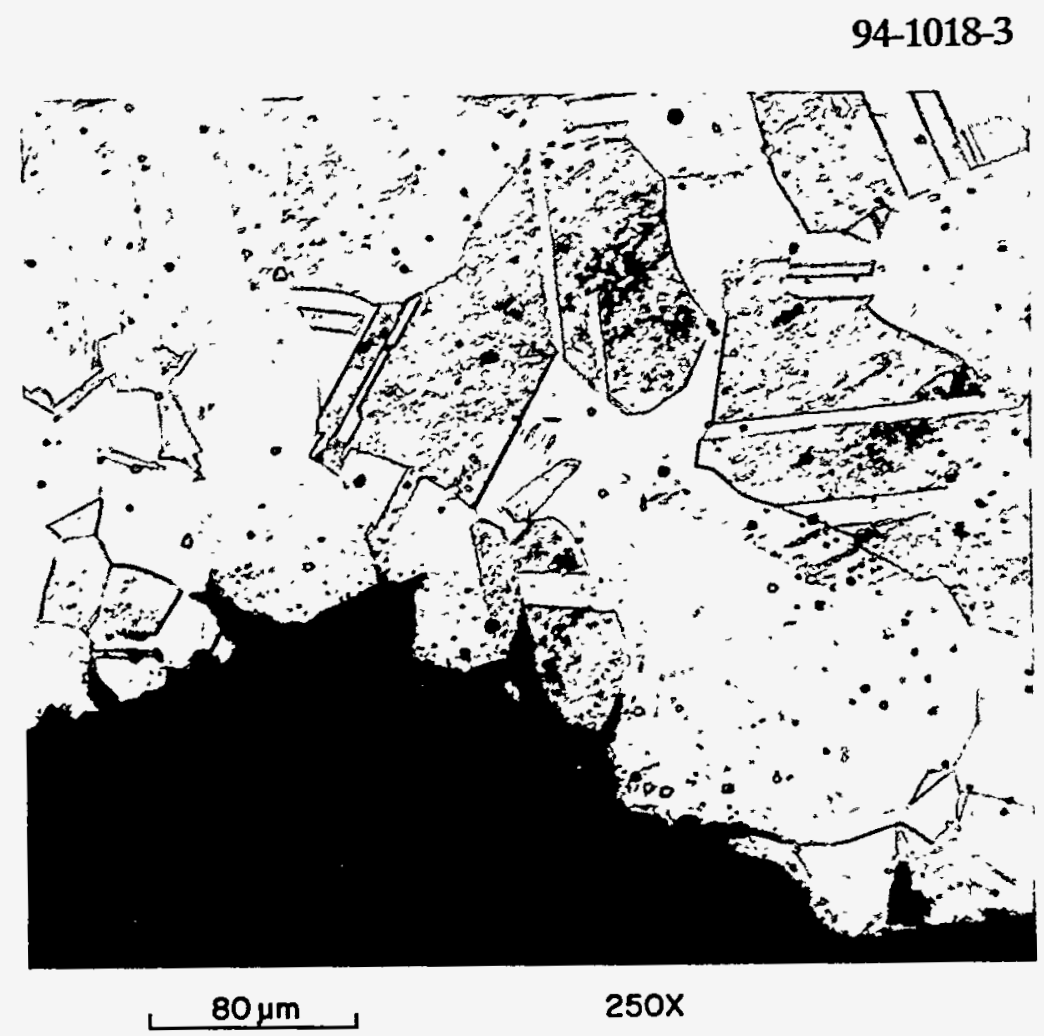

Fig. 9. Etched cross section of steam coil specimen.

tops of each pipe only) were defined as clock positions relative to this starting line. Additional information includes that, when viewed from the bottom center of the tank, the 6 o'clock position line is about 1 to $2 \mathrm{in}$. to the right of a visible weld on the surface of the inside cooling coil. The line defining the 10 o'clock position runs just below a pipe running in the horizontal direction.

The ultrasonic thickness gage used to make the wall thickness measurements was calibrated against two micrometers on a piece of $304 \mathrm{~L}$ stainless steel plate nominally $0.125 \mathrm{in}$. thick. With each micrometer, the thickness of the test plate was determined to be 0.121 in. Prior to entering the tank, the thickness of the test plate was determined to be 0.124 in. with the ultrasonic thickness gage; after leaving the tank, the same block measured 0.126 in. thick. As a result of these comparisons, the ultrasonic thickness measurements are considered to be 0.003 to 0.005 in. too high. The values recorded in Table 1 below represent the raw data collected with no adjustment for the fact that the measurements are suspected to be 3 to 5 mils too high. 
Table 1. Cooling coil pipe wall thickness (inches)

as a function of position

\begin{tabular}{lcccc}
\hline $\begin{array}{c}\text { Coil diameter } \\
\text { and position }\end{array}$ & 12 o'clock & 3 o'clock & 6 o'clock & 10 o'clock \\
\hline & & & & \\
Small, inside & 0.136 & 0.150 & 0.148 & 0.138 \\
& 0.146 & 0.143 & 0.151 & 0.152 \\
& 0.147 & 0.147 & 0.141 & 0.147 \\
& 0.152 & 0.156 & 0.153 & 0.150 \\
& 0.143 & 0.153 & 0.150 & 0.152 \\
Large, outside & 0.140 & 0.152 & 0.144 & 0.149 \\
& 0.147 & 0.154 & 0.148 & 0.146 \\
\hline
\end{tabular}

Since the nominal wall thickness of 1.5 -in. Sch. 40 pipe is 0.145 in., these numbers seem to represent the usual scatter around the nominal value. Most specifications allow up to $10 \%$ variations on pipe wall thickness, and these values indicate a maximum deviation of about 6 to $8 \%$.

To assess potential wall thickness changes due to bending, two positions were selected for measurements. One was on the third coil from the center as it bends from the horizontal orientation to rise vertically. The apex of this particular bend appeared to be the most seriously deformed (out-of-round). The apex of the bend from horizontal to vertical orientation on the fourth coil from the center was selected as representing a more "average" condition. Measurements (see Table 2) were taken in a plane at the bend apex on each pipe on the top and bottom and halfway in between on each side.

These values indicate relatively little wall thickness change due to pipe bending operations and that the fabrication operation is unlikely to account for any gross wall thinning observed in future investigations of these coils.

\section{RESULTS AND DISCUSSION FROM SUPPORTING LABORATORY TESTS}

In support of the failure analysis for the evaporator coil and for potential use in selecting alloys with superior corrosion resistance, a series of laboratory corrosion tests was performed. At 
Table 2 Wall thickness measurements for representative steam coils at a bend position

Wall thickness (inches)

Position when viewed from vessel center

Third coil bend

Fourth coil bend

Top

Side toward center

Bottom

Side away from center
0.170

0.160

0.154

0.159
0.153

0.152

0.144

0.143

the time these tests were performed, the initial observations associated with the coil failure analysis indicated only extreme general corrosion. As a result, weight loss tests were conducted in various caustic solutions in an attempt to "duplicate" the high corrosion rates for $304 \mathrm{~L}$ and potentially isolate a solution composition variable responsible for its poor performance.

Tests were conducted in round-bottom glass flasks placed in heating mantles with individual temperature controllers. Each flask had a glass specimen tree to position small metal coupons fully submerged in solution, at the air/solution interface, and wholly in the vapor above the solution. Each flask was also fitted with a four-bulb Allihn-type condenser.

Materials selected for testing represent a variety of candidate materials based primarily on general alloy content and those readily available in the author's laboratory (as opposed to materials known to be readily available in pipe sizes required for the evaporator). The test materials (see Table 3 for composition of test coupons) included:

- type 304L stainless steel (the present evaporator coil material of construction) containing an autogenous weld bead;

- type 309 stainless steel (similar to type 304L with somewhat higher $\mathrm{Cr}$ and $\mathrm{Ni}$ content);

- type $316 \mathrm{~L}$ stainless steel (similar to type $304 \mathrm{~L}$ but containing about $2 \%$ Mo where $304 \mathrm{~L}$ nominally has none);

- type 20Cb-3 (a "super" stainless steel containing $\mathrm{Cr}$ similar to type 304L but with substantially higher $\mathrm{Ni}, 2 \% \mathrm{Mo}, 3 \% \mathrm{Cu}$, and stabilized with $\mathrm{Nb}$ ); 
Table 3. Composition (weight percent) of coupon materials used in this investigation (Nominal composition of 20Mo-4 given rather than specific composition of coupons. Each alloy is a type of stainless steel and is referenced in the text by only the alloy designation.)

\begin{tabular}{lcccccc}
\hline & \multicolumn{5}{c}{ Coupon material } & \\
\cline { 2 - 7 } Element & $340 \mathrm{~L}$ & $316 \mathrm{~L}$ & 309 & $20 \mathrm{Cb}-3$ & $20 \mathrm{Mo}-4$ & $26-1$ \\
\hline $\mathrm{Fe}$ & bal & bal & bal & bal & bal & bal \\
$\mathrm{Cr}$ & 18.26 & 16.43 & 22.44 & 19.30 & 23.00 & 25.80 \\
$\mathrm{Ni}$ & 8.11 & 10.16 & 12.55 & 32.46 & 37.00 & 0.11 \\
$\mathrm{Mo}$ & 0.30 & 2.21 & - & 2.20 & 4.00 & 0.99 \\
$\mathrm{Mn}$ & 1.86 & 1.70 & 1.86 & 1.49 & 1.00 & 0.10 \\
$\mathrm{Si}$ & 0.56 & 0.62 & 0.27 & 0.74 & 0.5 & 0.24 \\
$\mathrm{Cu}$ & 0.30 & 0.38 & - & 3.07 & 1.00 & - \\
$\mathrm{Co}$ & - & 0.13 & - & - & - & 0.05 \\
$\mathrm{Nb}$ & - & - & - & 0.60 & 0.25 & 0.10 \\
$\mathrm{~V}$ & - & - & - & 0.13 & - & - \\
$\mathrm{C}$ & 0.02 & 0.02 & 0.06 & 0.01 & 0.02 & 0.002 \\
$\mathrm{~N}$ & 0.09 & 0.04 & - & 0.02 & - & 0.01 \\
$\mathrm{P}$ & 0.03 & 0.03 & 0.03 & - & 0.03 & 0.01 \\
$\mathrm{~S}$ & 0.002 & 0.014 & 0.001 & 0.003 & 0.03 & 0.01 \\
\hline
\end{tabular}

- type 20Mo-4 (another "super" stainless steel with slightly higher $\mathrm{Cr}$ and $\mathrm{Ni}$ than type $20 \mathrm{Cb}-3$ containing $4 \% \mathrm{Mo}$, a material so highly alloyed that it borders on nickel-base); and

- type 26-1 (unlike the other test alloys which are austenitic, this alloy is ferritic with $26 \% \mathrm{Cr}$ and $1 \%$ Mo and essentially no nickel).

Test coupons of each material (referenced hereafter by only the individual alloy designation) were exposed for nominally $24 \mathrm{~h}$ fully submerged, at the air/solution interface, and wholly in the vapor space in each of 12 different solutions. Exposures in each solution were accomplished at both $90^{\circ} \mathrm{C}$ and at the boiling temperature of the solution (which varied with composition). The concentrations of $\mathrm{NaOH}$ and chloride in the test solutions, along with other pertinent information, are summarized in Table 4.

Many of the tests revealed rather nondescript results. Specifically, none of the test specimens (at $90^{\circ} \mathrm{C}$ or at boiling, any composition or position on the specimen tree) associated with the 2 , 11 , or $26 \% \mathrm{NaOH}$ solutions (with or without added chlorides) revealed a corrosion rate in excess 
Table 4. Description of test solutions (made with reagent grade chemicals and demineralized water)

\begin{tabular}{|c|c|c|c|c|c|}
\hline $\begin{array}{l}\text { Solution } \\
\text { number }\end{array}$ & $\begin{array}{l}\text { NaOH, } \\
\text { grams } \\
\text { per liter } \\
\text { solution }\end{array}$ & $\begin{array}{c}\mathrm{NaOH} \\
\text { approx. } \\
\text { wt \% }\end{array}$ & $\mathrm{Cl}^{a}, \mathrm{ppm}$ & $\begin{array}{l}\text { Ambient } \\
\mathrm{pH}\end{array}$ & $\begin{array}{l}\text { Boiling } \\
\text { point, }{ }^{\circ} \mathrm{C}\end{array}$ \\
\hline 1 & 20 & 2.0 & 0 & $>13$ & 100 \\
\hline 2 & 20 & & 2,000 & & 100 \\
\hline 3 & 20 & & $10,000^{b}$ & & 100 \\
\hline $4 \cdot$ & 120 & 10.7 & 0 & -14 & 103 to 104 \\
\hline 5 & 120 & & 2,000 & & 103 to 104 \\
\hline 6 & 120 & & $10,000^{b}$ & & 103 to 104 \\
\hline 7 & 350 & 25.6 & 0 & $>14$ & 111 to 112 \\
\hline 8 & 700 & 41.2 & $\mathbf{0}$ & $>14$ & 127 to 128 \\
\hline 9 & 700 & & 2,000 & & 127 to 128 \\
\hline 10 & \multicolumn{3}{|c|}{-surrogate sludge ${ }^{c}-$} & & 104 to 105 \\
\hline 11 & \multicolumn{3}{|c|}{-acidified surrogate sludge- } & -0.0 & 112 to 113 \\
\hline 12 & \multicolumn{3}{|c|}{$\begin{array}{l}\text {-acidified surrogate sludge } \\
+500 \mathrm{ppm} \mathrm{F}^{d}\end{array}$} & -0.0 & 112 to 113 \\
\hline
\end{tabular}

\footnotetext{
${ }^{a} \mathrm{By}$ weight, added as $\mathrm{NaCl}$.

${ }^{b}$ Not entirely soluble.

'See Appendix 1 for complete description; simulates evaporator product, $\mathrm{pH}=13.3$, high nitrates and $80 \%$ solids.

${ }^{d}$ Added $500 \mathrm{ppm} \mathrm{F}$ as $\mathrm{NaF}$; small concentration of $\mathrm{Al}$ in surrogate and glass test vessels makes free $\mathrm{F}$ content uncertain.
}

of 0.5 mils per year. However, in the $41 \% \mathrm{NaOH}$ solution, $304 \mathrm{~L}$ and $316 \mathrm{~L}$ appear to be very susceptible to corrosion at the boiling point but much less susceptible at $90^{\circ} \mathrm{C}$. Table 5 summarizes corrosion rates calculated from weight loss for the $41 \% \mathrm{NaOH}$ solution with no chlorides added.

An interesting (and not altogether unexpected) result depicted in Table 5 is that for every case in the boiling $\left(127^{\circ} \mathrm{C}\right)$ solutions, the corrosion rate for coupons at the solution/vapor interface was at least slightly greater than for the corresponding coupons completely submerged. Although a specific mechanism for the present result has not been determined, it is a relatively common phenomenon that the availability of air (usually oxygen) at the interface location can accelerate the local corrosion rate substantially. Since the corrosion rates for the interface coupons were calculated based on the weight loss of the entire coupon surface, which included areas exposed to only vapor (very low corrosion rate) and entirely submerged (compare to the corresponding 
coupon data), the corrosion rate at the interface with air must have been quite high to generate the values given in Table 5. No coupon metallography was attempted.

Table 5. Corrosion rates based on weight loss of coupons exposed $24 \mathrm{~h}$ to $41 \% \mathrm{NaOH}$

\begin{tabular}{|c|c|c|c|c|c|c|}
\hline \multirow[b]{3}{*}{ Alloy } & \multicolumn{6}{|c|}{ Corrosion rate (mils per year) } \\
\hline & \multicolumn{3}{|c|}{$90^{\circ} \mathrm{C}$} & \multicolumn{3}{|c|}{$127^{\circ} \mathrm{C}$} \\
\hline & Vapor & Interface & Solution & Vapor & Interface & Solution \\
\hline $304 \mathrm{~L}$ & 0.0 & 0.5 & 0.0 & 0.0 & 65.3 & 51.6 \\
\hline $316 \mathrm{~L}$ & 0.4 & 0.8 & 8.4 & 0.0 & 102.0 & 74.1 \\
\hline 309 & 0.0 & 0.0 & 0.0 & 0.0 & 1.1 & 0.4 \\
\hline $20 \mathrm{Cb}-3$ & 0.0 & 0.0 & 0.0 & 0.0 & 0.8 & 0.4 \\
\hline $20 \mathrm{Mo}-4$ & 0.0 & 0.0 & 0.0 & 0.0 & 1.3 & 0.0 \\
\hline $26-1$ & 0.0 & 0.0 & 0.0 & 0.2 & 0.1 & 0.0 \\
\hline
\end{tabular}

Another interesting result is that the corrosion rate of $316 \mathrm{~L}$ was somewhat higher than that for $304 \mathrm{~L}$ for comparable conditions. In light of the performance of the other alloys (particularly the low corrosion rate of 309), it may be that the low Cr content of $316 \mathrm{~L}$ (about $2 \%$ less than $304 \mathrm{~L}$, 6\% less than 309) renders the Mo content of $316 \mathrm{~L}$ relatively ineffective for improving passive film stability in this environment.

For each of the $309,20 \mathrm{Cb}-3,20 \mathrm{Mo}-4$, and 26-1 coupons, the addition of about $2000 \mathrm{ppm} \mathrm{Cl}$ to the boiling $41 \% \mathrm{NaOH}$ solution led to very slight increases in corrosion rates (but none in excess of 2 mils per year). It is somewhat curious that the corrosion rate of $304 \mathrm{~L}$ and $316 \mathrm{~L}$ decreased substantially in the solution containing $2000 \mathrm{ppm} \mathrm{Cl}$ compared to the pure $\mathrm{NaOH}$ solution. This is likely to be an artifact of testing in that the pure $41 \% \mathrm{NaOH}$ solution was reused for the test with the addition of $2000 \mathrm{ppm} \mathrm{Cl}$ and that only the $304 \mathrm{~L}$ and $316 \mathrm{~L}$ specimens received a fresh surface finish prior to the test. No testing to reproduce this unusual result was attempted.

None of the alloys revealed any tendency toward corrosion in the as-received sludge surrogate. Only minor corrosion rates were observed after the nitric acid addition to modify the $\mathrm{pH}$ to near zero. The addition of $500 \mathrm{ppm} F$ to the acidified sludge surrogate further increased corrosion rates only slightly. Pertinent corrosion rate data in mils per year for the latter case appear in Table 6. 
Table 6. Corrosion rates (mils per year) calculated from weight loss for coupons exposed in acidified surrogate sludge (nitric acid addition to $\mathrm{pH}$ near 0 ) with approximately $500 \mathrm{ppm}$ fluoride addition

\begin{tabular}{|c|c|c|c|c|c|c|}
\hline \multirow[b]{2}{*}{ Alloy } & \multicolumn{3}{|c|}{$90^{\circ}$} & \multicolumn{3}{|c|}{$112^{\circ} \mathrm{C}$} \\
\hline & Vapor & Interface & Solution & Vapor & Interface & Solution \\
\hline 304L & 0.0 & 1.9 & 1.9 & 2.5 & 3.9 & 4.1 \\
\hline $316 \mathrm{~L}$ & 1.3 & 3.3 & 4.6 & 6.2 & 7.5 & 8.8 \\
\hline 309 & 0.0 & 0.0 & 0.4 & 0.9 & 1.5 & 2.0 \\
\hline $20 \mathrm{Cb}-3$ & 0.0 & 0.7 & 1.4 & 3.2 & 3.6 & 3.8 \\
\hline $20 \mathrm{Mo}-4$ & 0.0 & 0.2 & 1.5 & 2.0 & 3.0 & 5.0 \\
\hline $26-1$ & 0.0 & 0.0 & 0.4 & 0.7 & 1.2 & 2.2 \\
\hline
\end{tabular}

Although it is possible to question the composition and absolute relevancy of this specific evaporator sludge surrogate, these data (maximum general corrosion rate for 304L of 4.1 mils per year) suggest that, in the absence of other factors, the temporary "off-normal" acid condition observed in the evaporator a number of years ago was not likely responsible for the extreme general corrosion of the failed coil.

At the conclusion of this brief set of coupon exposures, it was not clear what factors might contribute to the extreme general corrosion observed on the failed evaporator tube. With the exception of the boiling $41 \% \mathrm{NaOH}$ test, which is much more concentrated than the nominal $5 \% \mathrm{NaOH}$ found in service, type 304L stainless steel proved to be very resistant to all of the test solutions. In practice, however, some relatively benign solutions can be made aggressive under heat- transfer conditions, particularly if the solution concentrates, as in a splash zone.

A splash zone is typically thought of as an area at the top of a containment vessel that is intermittently wetted by the process solution. The intermittent wetting can be a result of splashing (e.g., bubbling action of boiling) or periodic solution level changes. Corrosion in the splash zone is often accelerated by many factors, including the presence of air creating a disproportionate fraction of air/solution interface. In addition, if the splash zone is heated, evaporation of the "splashed material" above the nominal solution level may substantially increase the concentration of aggressive species in the remaining material. In this way, harmless nominal concentrations may reach very corrosive concentrations in localized areas above the nominal solution level.

To examine this concept for the evaporator coil, a rather crude experiment to simulate concentrating effects for dilute solutions was performed. Small glass dishes with watch glass tops 
were placed in a furnace operating at 106 to $107^{\circ} \mathrm{C}$. Specimens of each of the six alloys examined previously were laid flat (major area in horizontal orientation) in the dishes. A few drops of test solution were placed on each coupon every few hours (less frequently on weekend days) for a week. The amount of solution was not carefully metered from the dropper but was sufficient to wet the entire horizontal surface with a little excess. The test solutions used included the pure 2 and $11 \% \mathrm{NaOH}$ solutions as well as the sludge surrogate as-received $(\mathrm{pH} 13)$ and acidified ( $\mathrm{pH} \mathrm{0).} \mathrm{Based} \mathrm{on} \mathrm{periodic} \mathrm{observations,} \mathrm{it} \mathrm{was} \mathrm{clear} \mathrm{that} \mathrm{the} \mathrm{solutions} \mathrm{baked} \mathrm{to} \mathrm{dryness} \mathrm{(leaving}$ a "salt cake") in only a few minutes after each fluid addition.

Table 7 gives the corrosion rate in mils per year-based on weight loss and total estimated time of wetness at $15 \mathrm{~min}$ per fluid addition-for each alloy. The reader should be aware that there is significant uncertainty regarding the precise surface area of each coupon exposed (due to crust formation and the occluded area in contact with the glass dish) and the time of wetness. These factors are roughly the same for each specimen/alloy, so the relative corrosion rates so "calculated" have more meaning than the absolute values given.

Table 7. Corrosion rates based on weight loss for the "bake to dryness" experiments

\begin{tabular}{lcccc}
\hline & \multicolumn{4}{c}{ Corrosion rate (mils per year) } \\
\cline { 2 - 5 } \multicolumn{1}{c}{ Alloy } & $\begin{array}{c}\text { Drops of } \\
2 \% \text { NaOH }\end{array}$ & $\begin{array}{c}\text { Drops of } \\
11 \% \text { NaOH }\end{array}$ & $\begin{array}{c}\text { As-received } \\
\text { surrogate sludge }\end{array}$ & $\begin{array}{c}\text { Acidified } \\
\text { sludge }\end{array}$ \\
\hline & & & & \\
$304 \mathrm{~L}$ & 0 & 20 & 0 & 16 \\
$316 \mathrm{~L}$ & 1 & 20 & 0 & 19 \\
309 & 1 & 6 & 0 & 16 \\
$20 \mathrm{Cb}-3$ & 2 & 36 & 0 & 18 \\
$20 \mathrm{Mo}-4$ & 2 & 23 & 0 & 14 \\
$26-1$ & $-a$ & 6 & 7 & \\
\hline
\end{tabular}

"Specimen "lost" due to reaction/bonding with the glass dish.

Due to the uncertainties mentioned above, the data in Table 7 are not remarkably conclusive; however, some important trends are evident. For example, it appears that droplets of the $11 \%$ $\mathrm{NaOH}$ solution can be made sufficiently aggressive to corrode all of these materials significantly at $107^{\circ} \mathrm{C}$. This is in contrast to the more standard immersion tests using $11 \% \mathrm{NaOH}$, which 
generated corrosion rates no higher than 0.5 mils per year for all materials. Likewise, the acidified surrogate sludge solution was much more aggressive to these alloys in the wet/dry cycles. These data seem to confirm that corrosion conditions on portions of the heating coil that are intermittently covered with solution (or in a splash zone) may be much more aggressive than on the average position for the pipe. This is consistent with the apparent location of the pipe failure under study, which was at the top of the coil in a region expected to be only intermittently wetted/splashed.

\section{EVAPORATOR EXPERIENCE AT OTHER DEPARTMENT OF ENERGY SITES}

At the Westinghouse Hanford Company (WHC) site near Richland, Washington, a waste stream similar to that processed in the Melton Valley system in Oak Ridge is concentrated in an evaporator. The evaporator receives alkaline, high-nitrate wastes and concentrates these (volume reduction) for storage. Although many details of evaporator operation are unknown to the authors, 304L has been used for many years in evaporator construction at WHC. In the past, WHC experienced some premature failure difficulties with 304L heating coils and, without metallographic confirmation, identified caustic SCC as a likely culprit. ${ }^{2}$ WHC personnel subsequently decided that removal of oxygen from the system would eliminate caustic cracking of the 304L.

As a result, WHC now operates their evaporator ${ }^{2}$ under rough vacuum (50 torr). This effectively removes most oxygen but, perhaps more importantly, also permits evaporation to occur at a much lower temperature $\left(60\right.$ to $65^{\circ} \mathrm{C}$ ) than previously (near $110^{\circ} \mathrm{C}$ ). The latter factor alone is of major significance according to the data presented in this report. In any case, WHC personnel $^{2}$ do not report any corrosion problems for $304 \mathrm{~L}$ at the reduced temperature.

The Westinghouse Savannah River Company (WSRC) near Aiken, South Carolina, also has a waste evaporator system not unlike that at Melton Valley. At WSRC, ${ }^{3}$ the waste concentrate is highly alkaline (order of $5 \mathrm{M}$, or near $20 \% \mathrm{NaOH}$ ) with high nitrate concentration (order of $3 \mathrm{M}$ ) and smaller amounts of other species including nitrites (used as an inhibitor for storage tank corrosion). In the past, variable success with $304 \mathrm{~L}$ heating coils (steam at about $170^{\circ} \mathrm{C}$ ) led to a laboratory study to investigate the utility of other materials. WSRC found ${ }^{3}$ that $304 \mathrm{~L}$ was adequate for the evaporator tank (lower temperature than coils, not a heated surface), but that alloy G3 or G30 (nickel-base alloys; UNS N06985 and N06030, respectively) tubes were required to handle the caustic corrosion aspects. 


\section{PERTINENT LITERATURE INFORMATION ON CAUSTIC CORROSION}

In general, type 304/304L stainless steel is considered compatible with various hydroxide solutions. Standard handbook ${ }^{4-7}$ corrosion data for 304 in hydroxide solutions indicate very low general corrosion rates at moderate concentrations and temperatures. The general corrosion rate is indicated to increase significantly as the temperature approaches the solution boiling point, particularly as the caustic concentration increases. No data for hot hydroxide solutions rich in nitrates and other waste components are readily available, although one brief study ${ }^{8}$ defining the material selection for the new Melton Valley storage tanks (which receive evaporator concentrate) indicates excellent corrosion resistance of $304 \mathrm{~L}$ in this environment to at least $66^{\circ} \mathrm{C}$.

Perhaps due primarily to interest in tube failures associated with pressurized-water reactor steam generators in the 1970s, susceptibility to SCC of austenitic stainless steels such as 304/304L in hot hydroxide solutions was identified and documented in some detail (e.g., see refs. 4, 7, and 9-14). In general, 304/304L is considered susceptible to caustic SCC at temperatures near and above the boiling point of the solutions and, typically, in relatively concentrated solutions. Further, reports seem to indicate that SCC morphology in caustic is transgranular for concentrated hydroxides $(>40 \%)$ and intergranular for relatively dilute $(10 \%)$ hydroxides, but the temperature must be significantly higher than boiling to develop cracking in the latter case.

Another important variable that has been recognized is the relative electrochemical potential of 304/304L in hydroxide solutions. Some authors have specifically studied this concept by controlling potential with applied voltage and/or chemical additives and showed cracking and corrosion rate can be controlled in this manner. ${ }^{12-15}$ One author ${ }^{12}$ commented that at sufficiently high potential, very dense (overlapping) pitting would yield essentially uniform thinning and identified potential ranges associated with different types of cracking.

Two reports observed that small quantities of nitrates in the hydroxide solutions inhibit caustic SCC $^{13,14}$ due to an increase in potential, but one further comments that nitrate did seem to increase general corrosion of 304 at high temperatures and high caustic concentrations. ${ }^{14}$ Interestingly, one report ${ }^{14}$ also observed that low levels of halides $(\mathrm{Cl}, \mathrm{F})$ actually retarded cracking of stainless steels in hot caustic solutions. (Lab results in this investigation showed a decrease in the general corrosion rate as a result of chloride additions.) Another interesting result is that sensitization (presence of carbides at grain boundaries) of 304 may slightly improve resistance to caustic cracking. ${ }^{9.10}$ 
Yasuda et al. ${ }^{15}$ report several observations pertinent to the study of the failed steam coil. Consistent with our laboratory results, they found 316 more susceptible to corrosion in 10 to $40 \%$ $\mathrm{NaOH}$ solutions than 304 . They also found extreme temperature sensitivity for corrosion of submerged specimens, with little or no corrosion at $110^{\circ} \mathrm{C}$ in $40 \% \mathrm{NaOH}$ for either alloy but high corrosion rates at $129^{\circ} \mathrm{C}$ (boiling). This sensitivity was ascribed to insufficient dissolved oxygen in solution at the boiling point to maintain a passive condition on the specimens. The authors ${ }^{15}$ also commented that intergranular attack was associated with passive (relatively high potential) corrosion conditions rather than active corrosion conditions. Especially pertinent to the steam coil investigation, Yasuda et al. ${ }^{15}$ also comment that passivity is more difficult to maintain under heat-transfer conditions. This was due to concentration of caustic in the vicinity of the metal surface caused by increased temperature and degradation of the passive film by bubbles of evaporated water.

\section{SUMMARY AND CONCLUSIONS}

Analysis of the section of pipe removed from the $2 \mathrm{~A} 2$ evaporator and the associated lab corrosion tests and literature information revealed the following information:

- The leak site(s) were surrounded by a large area of very high general corrosion rate; in two calendar years of service (even less actual duty time), 145 mils of wall thickness were penetrated at leak sites, and large areas developed where at least half the wall thickness was corroded. This penetration corresponds to anywhere from 50 to 60 mils per year to even higher values, depending on the actual duty time.

- Metallography in and around the leak site revealed shallow intergranular corrosion at attacked surfaces. No cracks or pits were observed, although some localized areas did exhibit greater attack than the average in that region and thus resembled pits.

- No incidences of high inclusion density, carbide precipitates, or weld problems (failure not near a weld) were observed. The videotape of the internal inspection revealed no particular weld corrosion, and the weld in the lab immersion exposures (304L specimen) was not attacked differently from base metal.

- Isothermal (no heat transfer) corrosion tests in the laboratory in hydroxide solutions indicate that very high concentrations of hydroxide (order of $40 \%$ ) at boiling are required to achieve the magnitude of general corrosion rates observed on the failed pipe. The nominal hydroxide concentration in evaporator duty is near $5 \%$. 
- A "splash zone" effect appears to be a mechanism by which the nominal concentration of $5 \%$ hydroxide in the evaporator can be concentrated to corrosive levels near the top of the working solution level. This was "confirmed" in crude laboratory tests which showed that $304 \mathrm{~L}$ was essentially immune to general corrosion in $11 \% \mathrm{NaOH}$ but was subject to substantial corrosion rates when drops of the same solution were allowed to bake to dryness on these coupons. Any other role of the heat-transfer surface in this mechanism is uncertain.

- The "splash zone" effect of increased corrosivity is consistent with the observed failure location, i.e., on the topmost horizontal winding of a steam coil. Portions of the coil completely immersed would not be subject to this problem, except perhaps under deposits.

- Intense corrosion of the steam coil at the splash zone but little/no attack on the vessel walls at the splash zone is to be expected because the vessel wall is not heated; in fact, condensate may continually "wash" the vessel walls due to the lower temperature at this location. This is consistent with results of the remote video viewing of the $2 \mathrm{~A} 2$ internals.

- Moderate intergranular corrosion was observed at the advancing corrosion front. The cause of this form of corrosion may be related to the oxidizing potential of the nitrate concentration in the evaporator creating a mild effect on a marginally passive surface at the splash zone.

- Very low corrosion rates in lab immersion tests in acidified sludge surrogate indicate that the simple presence of off-normal (acid) feed in the evaporator is not likely to be the single cause of the coil failures. Higher corrosion rates were found for splash zone tests with acidified sludge, but the same was true of nominal alkaline feed.

These data and observations indicate that $304 \mathrm{~L}$ is nominally a good alloy for evaporator tank service and immersed heating coils but has marginal corrosion resistance as heated coils in the splash zone (top of solution level). It is suspected that there may be other steam coils in the 2A2 unit with thinned regions that simply have not spent sufficient duty time in the critical environment to have been penetrated. There is insufficient information to determine why the older A2 evaporator (much longer service time than 2A2) has not experienced a coil failure. It may be that a batch or two containing a particular constituent (or concentration thereof) was processed in the $2 \mathrm{~A} 2$ unit that was especially aggressive in the splash zone. In any case, it appears that without a lower operating temperature or different material for the steam coils, this will continue to be a potential "life-limiting" problem for the evaporators. 


\section{RECOMMENDATIONS}

Laboratory studies to identify specific corrosion mechanisms and rates (and therefore to identify superior materials) are recommended in anticipation of continued evaporator activity for the forseeable future. Such studies could include (but should not be limited to) more sophisticated analysis of the role of heat transfer with "hot wall" experiments on a variety of alloys and evaporator solutions. In addition, electrochemical polarization to study the influence of small variations in constituents of the solutions would improve understanding of the passivity limits of candidate alloys.

An opportunity to examine other steam coils at various positions inside the evaporator might confirm or refute some of the hypotheses regarding positions most susceptible to failure in the proposed scenario. Prime opportunity might include the decommissioning of a vessel or another internal inspection.

\section{ACKNOWLEDGMENTS}

The authors would like to recognize the contributions of several individuals to this effort. S. Childs performed much of the tube handling and wall thickness measurements at the hot cell. P. S. Kirkham, Sr., was instrumental in arranging access to the new evaporator for coil wall thickness measurements and supported the activities associated with this difficult entry. J. C. Griess, Jr., D. F. Wilson, and J. R. DiStefano provided review of the manuscript and helpful discussions. M. R. Upton prepared the final report, $K$. Spence edited the report, and G. R. Carter performed the quality review.

\section{REFERENCES}

1. "Preliminary Investigation of Steam Coil Failures in LLW System Evaporator," Martin Marietta Energy Systems Internal Memorandum originated 1/31/85 by J. L. Snyder.

2. A. P. Larrick, Westinghouse Hanford Company, Richland, Wash., personal communication to S. J. Pawel, Oak Ridge Natl. Lab., Oak Ridge, Tenn., May 1994.

3. C. F. Jenkins, Westinghouse Savannah River Company, Aiken, S.C., in a presentation at the 13th Tank Structural Integrity Workshop, Richland, Wash., August 1994. 
4. ASM Metals Handbook, 9th ed., Vol. 13, ASM International, Materials Park, Ohio, 1987, 1175-78.

5. Corrosion Resistance Tables, 2d ed., ed. P. A. Schweitzer, Marcel Dekker, Inc., New York, $1986,930-36$ and $1036-46$.

6. Compass Corrosion Guide, 2 d ed., ed. K. M. Pruett, Compass Publications, La Mesa, Calif., 1983, A70, A82.

7. Corrosion Resistance of Nickel and Nickel-Containing Alloys in Caustic Soda and Other Alkalies, INCO Corrosion Engineering Bulletin 2, The International Nickel Company, New York, 1973, 13-15.

8. S. J. Pawel, Preliminary Investigation of Corrosion of 1020 Mild Steel and Types 304L and 316L Stainless Steels in Liquid Low Level Wastes Simulating Melton Valley Storage Requirements, Y/DV-1149, Martin Marietta Energy Systems, Inc., Y-12 Plant, July 1992.

9. I. L. Wilson, F. W. Pement, and R. G. Aspden, "Effect of Alloy Structure, Hydroxide Concentration, and Temperature on the Caustic Stress Corrosion Cracking of Austenitic Stainless Steels," Corrosion 30(4), 139 (1974).

10. I. L. W. Wilson and R. G. Aspden, "The Influence of Specimen Type and Heat Treatment on the Caustic Stress Corrosion Cracking of Some Stainless Alloys," Corrosion 32(5), 193 (1976).

11. A R. Mcllree and H. T. Michels, "Stress Corrosion Behavior of Fe-Cr-Ni and Other Alloys in High Temperature Caustic Solutions," Corrosion 33(2), 60 (1977).

12. Y. S. Park et al., "Stress Corrosion Cracking and Anodic Behavior of AISI 304 Stainless Steel, Inconel 600, and Incoloy 800 Straining in Boiling $\mathrm{NaOH}$ Solutions," Corrosion 34(12), 413 (1978).

13. Y. S. Park, A. K. Agrawal, and R. W. Staehle, "Inhibitive Effect of Oxyanions on the Stress Corrosion Cracking of Type 304 Stainless Steel in Boiling 20N NaOH Solution," Corrosion 35(8), 333 (1979).

14. F. W. Pement, I. L. W. Wilson, and R. G. Aspden, "Stress Corrosion Cracking Studies of High Nickel Austenitic Alloys in Several High Temperature Aqueous Solutions," Mater. Perform. 19(4), 43 (1980).

15. M. Yasuda et al., "Corrosion Behavior of 18-8 Stainless Steels in Hot Concentrated Caustic Soda Solutions under Heat-Transfer Conditions," Corrosion 41(12), 720 (1985). 


\section{APPENDIX 1 \\ COMPOSITION OF EVAPORATOR SLUDGE SURROGATE}





\section{APPENDIX 1}

\section{COMPOSITION OF EVAPORATOR SLUDGE SURROGATE}

Various studies have required quantities of typical evaporator product for study in the laboratory. One such mixture was created to simulate the "sludge" found in the Melton Valley storage tanks. This surrogate material is very similar in composition to the tank bottoms except that it contains no radioactive component. The ORNL Chemical Technology Division created surrogate sludge of the following composition using the "recipe" given below. The product is a white slurry with a very high fraction $(>80 \%)$ solids. Nominal $\mathrm{pH}$ of the mixture is 13.3 .

\begin{tabular}{lrrlrr}
\multicolumn{2}{c}{ Soluble components } & \multicolumn{2}{c}{ wt \% } & & \multicolumn{2}{c}{ Insoluble components } & wt \% \\
$\mathrm{NaCl}$ & $0.89 \mathrm{~kg}$ & 1.3 & $\mathrm{CaCO}_{3}$ & $37.06 \mathrm{~kg}$ & 60.5 \\
$\mathrm{KNO}_{3}$ & $9.08 \mathrm{~kg}$ & 12.8 & $\mathrm{Fe}(\mathrm{OH})_{3}$ & $0.33 \mathrm{~kg}$ & 0.5 \\
$\mathrm{NaNO}_{3}$ & & 80.3 & $\mathrm{Ca}(\mathrm{OH})_{2}$ & $13.14 \mathrm{~kg}$ & 21.4 \\
added & $21.12 \mathrm{~kg}$ & & $\mathrm{Al}(\mathrm{OH})_{3}$ & $1.47 \mathrm{~kg}$ & 2.4 \\
produced & $35.78 \mathrm{~kg}$ & & $\mathrm{Mg}(\mathrm{OH})_{2}$ & $8.08 \mathrm{~kg}$ & 13.2 \\
$\mathrm{Na}_{2} \mathrm{CO}_{3}$ & $4.01 \mathrm{~kg}$ & 5.7 & $\mathrm{SiO}_{2}$ & $\underline{1.22 \mathrm{~kg}}$ & 2.0 \\
\cline { 2 - 3 } & $70.88 \mathrm{~kg}$ & & & $61.30 \mathrm{~kg}$ &
\end{tabular}

Water content $118.12 \mathrm{~kg}$

Mixing instructions for surrogate sludge:

1. Obtain a clean, 200-L (55-gal) stainless steel drum. Add $38 \mathrm{~L} \mathrm{(37.92} \mathrm{kg)} \mathrm{of} \mathrm{water} \mathrm{to} \mathrm{the}$ drum. Initiate stirring with an agitator, and continue stirring throughout the procedure.

2. Obtain $16.86 \mathrm{~kg}$ of sodium hydroxide $(\mathrm{NaOH})$. Slowly add the $\mathrm{NaOH}$ to the agitated water. $\mathrm{Be}$ aware that adding $\mathrm{NaOH}$ to water will cause heat to be generated. Control the temperature with addition rate. Proceed to the next step when all of the $\mathrm{NaOH}$ is dissolved.

3. In another clean container, add $1.25 \mathrm{~kg}$ of iron nitrate $\left[\mathrm{Fe}\left(\mathrm{NO}_{3}\right)_{3} \bullet 9 \mathrm{H}_{2} \mathrm{O}\right]$ and dissolve in $19 \mathrm{~L}(18.96 \mathrm{~kg})$ of water. When dissolved, slowly add the solution to the drum. It is important to add slowly to enhance the formation of small particles of $\mathrm{Fe}(\mathrm{OH})_{3}$.

4. Add $41.90 \mathrm{~kg}$ of calcium nitrate $\left[\mathrm{Ca}\left(\mathrm{NO}_{3}\right)_{2} \bullet 4 \mathrm{H}_{2} \mathrm{O}\right]$ to another clean container. Dissolve in $19 \mathrm{~L}(18.96 \mathrm{~kg})$ of water. When dissolved, slowly add the solution to the drum. It is important to add slowly to enhance the formation of small particles of $\mathrm{Ca}(\mathrm{OH})_{2}$. 
5. Add $7.10 \mathrm{~kg}$ of aluminum nitrate $\left[\mathrm{Al}\left(\mathrm{NO}_{3}\right)_{3} \bullet 9 \mathrm{H}_{2} \mathrm{O}\right]$ to another clean container. Dissolve in $4.73 \mathrm{~L}$ (4.72 kg) of water. When dissolved, slowly add the solution to the drum. It is important to add slowly to enhance the formation of small particles of $\mathrm{Al}(\mathrm{OH})_{3}$.

6. In a separate container, dissolve $0.89 \mathrm{~kg}$ of sodium chloride $(\mathrm{NaCl}), 4.01 \mathrm{~kg}$ of sodium carbonate $\left(\mathrm{Na}_{2} \mathrm{CO}_{3}\right), 9.08 \mathrm{~kg}$ of potassium nitrate $\left(\mathrm{KNO}_{3}\right)$, and $21.12 \mathrm{~kg}$ of sodium nitrate of $\left(\mathrm{NaNO}_{3}\right)$ in $38 \mathrm{~L}(37.92 \mathrm{~kg})$ of water. Gentle heating may be required to dissolve $\mathrm{NaNO}_{3}$. Add to the drum when dissolved.

7. Slowly add $37.06 \mathrm{~kg}$ of calcium carbonate $\left[\mathrm{Ca}\left(\mathrm{CO}_{3}\right)\right]$ and $8.08 \mathrm{~kg}$ of magnesium hydroxide $\left[\mathrm{Mg}\left(\mathrm{OH}_{2}\right)\right]$ to the drum.

8. Dissolve $0.076 \mathrm{~kg}$ of sodium hydroxide $(\mathrm{NaOH})$ in $0.15 \mathrm{~L}$ of water. When dissolved, add $1.59 \mathrm{~kg}$ of silicic acid $\left(\mathrm{H}_{2} \mathrm{SiO}_{3}\right)$ to the $\mathrm{NaOH}$ solution. Add mixture to the drum. Mix until homogeneous. 
ORNL/TM-12974

\section{INTERNAL DISTRIBUTION}

1-2. Central Research Library

3. Document Reference Section

4-5. Laboratory Reference Section

6. Laboratory Records, ORNL RC

7. ORNL Patent Section

8-10. M\&C Records Office

11. J. R. DiStefano

12. J. C. Griess (consultant)

13. H. W. Hayden

14. L. L. Jacobs

15-19. J. R. Keiser

20. P. S. Kirkham

21-24. H. F. Longmire

25. K. E. Lott
26. K. H. Luk

27. J. R. Mayotte

28. H. E. McCoy

29. J. E. Pawel

30-34. S. J. Pawel

35. W. R. Reed

36. C. B. Scott

37. J. L. Snyder

38. L. J. Turner

39. D. F. Wilson

40. H. W. Foglesong (Consultant)

41. E. L. Menger (Consultant)

42. J. G. Simon (Consultant)

43. K. E. Spear (Consultant)

\section{EXTERNAL DISTRIBUTION}

44. DOE, OAK RIDGE OPERATIONS OFFICE, P.O. Box 2001, Oak Ridge, TN 37831-8600

Assistant Manager for Energy Research and Development

45-46. DOE, OFFICE OF SCIENTIFIC AND TECHNICAL INFORMATION, Office of Information Services, P.O. Box 62, Oak Ridge, TN 37871

For distibution by microfiche as shown in DOE/OSTI-4500, Category Distribution UC-902 (Environmental Sciences) 